THE PHOTOGRAPHED OTHER: Interplays of Agency in Tourist Photography in Cusco, Peru

\begin{abstract}
This paper unpacks the interplays of agency that emerge as locals are photographed by tourists. It explores the larger forces that constrain photographic performances within dominant western mythologies of the exotic Other. In unpacking the seemingly fleeting moments of photographic encounters, it contends tourist photography does not merely perpetuate spaces of exclusion through dependency and disempowerment, but mobilises spaces of empowerment, independence and self-determination within local communities. In exploring such issues, the paper addresses: the complexities of agency and power within tourist photography, the opportunities for empowerment through self-directed performances, the potential of photographic encounters to mobilise fleeting moments of togetherness and social exchange, and the opportunities tourist photography affords in reigniting and reinforcing the cultural identity of local communities.
\end{abstract}

\title{
Keywords
}

Photography, performance, agency, commodification, host, Other 


\section{THE PHOTOGRAPHED OTHER: Interplays of Agency in Tourist Photography in Cusco, Peru}

\section{INTRODUCTION}

For decades authors have reflected upon the fundamental role of photography in tourism (Sontag, 1976; Bæderholt, Haldrup, Larsen \& Urry, 2004; Chalfern, 1979; Crang, 1997). As Haldrup \& Larsen (2003) suggest: "taking photographs is an emblematic tourist practice" (: 23). However, where research attends to photographic practice, it does so in a relatively ad-hoc manner. Authors explore the visual in the tourist experience (see Urry, 1990; Crouch \& Lübbren, 2003), social relationships produced through photography (Haldrup \& Larsen, 2003), photography as embodied practice (Jokinen \& Veijola, 2003), or photographing in particular contexts (Edensor, 1998). Where research addresses locals being photographed, attention centres on the production of locals as 'exoticised' others; markers whom tourists gaze upon through a lens of myth (Adler, 1989; Albers \& James, 1984; Caton \& Santos, 2008; Edwards, 1996). Thus, locals become embedded within a hermeneutic circle as tourists strive to capture ideological understanding produced through western mythologies. Photography becomes reduced to validating stereotypes (Caton \& Santos, 2008; Frankland, 2009; Mellinger, 1994; Markwick, 2001; Martinez \& Albers, 2009; Waitt \& Head, 2002) as locals are positioned as abstracted and anonymous 'natives'; 'indigenous' and 'primitive' representations of culture (Albers \& James, 1984; Cannon-Hunter, 2008; Dann, 1996).

Building upon Palmer \& Lester (2007) and Cohen, Nir \& Almagor (1992), this paper unpacks the agency of locals within photographic encounters. As Cohen et al (1992) suggest, "it is doubtful...that photography has a merely banalising or denigrating effect on local cultures...the penetration of photography may have had more profound and unexpected consequences, like increased self-consciousness, which need closer study" (: 229). Photography is not an end in itself and reflexive questioning of the relationship between the photographer and those being photographed is vital (Teymour, 1993). It emerges as performances via ontological active doings (see Coleman \& Crang, 2002; Crang, 1997; Edensor, 1998; 2001; Scarles, 2009). It is not merely a process of abstraction and exemplification, but is manifest through negotiated embodied performances between agents that are themselves imbued within culture, society, power, politics and agency (see also Franklin \& Crang, 2001; Santos \& 
Yan, 2008). This paper seeks to unpack the interplays of agency that emerge as locals being photographed negotiate the complexities of performing amongst larger, third party forces that exist within the wider global political economies and western tourist mythologies. It investigates the potential effects such interplays have on the sociocultural frameworks of those being photographed; identifying the potential for facilitating cycles of disempowerment and dependency, but vitally, embracing opportunities to empower local communities.

\section{THE COMPLEXITIES OF PHOTOGRAPHIC ENCOUNTERS}

As Coleman \& Crang (2002) realise, the intellectual vision of local cultures has been inflected by the creation of a spectacle of diversity for imperialist consumption by tourists. As tourists embrace technological advances of digital photography, such envisioning and consumption intensifies as tourists watch their recordings immediately; deciding whether to keep, erase or retake photographs (see Jansson, 2007; Prideaux \& Colgan, 2010). Photography actively creates new realities as tourists experiment with place and use digital technologies as an avenue for self-expression and self-presentation (van House et al, 2004). Thus, anthropological understandings of authenticity and commodification imbue tourists' photographic practices as they stage and expose subjects to fit discursive narratives as both anticipated and experienced (see Crang, 1997a; Edensor, 1998; Sontag, 1976). Despite the multiplicity of potential subjective interpretations, mediated representations become authoritative (Bruner, 1991; Bruner \& Kirshenblatt, 2005; Caton \& Santos, 2008) as tourists become active directors of photographic encounters (Baerenholdt et al, 2004; Crang, 1997a; Scarles, 2009). Locals are framed as the exotic Other; consumed visually through the camera lens (Albers \& James, 1984; Martinez \& Albers, 2009; Caton \& Santos, 2008; Frankland, 2009; Whittaker, 2009). This paper therefore unpacks the interplays of agency that facilitates the objectification of locals as they become 'tourees' (Pearce, Kim \& Lussa, 1998); moulded and disciplined (Adler, 1989) and cast into roles (Crang 1997b).

Tourist spaces and the performances enacted within them are highly regulated and ordered (Edensor, 2004); immersed in relations of power, agency and politics from both internal and external forces. They are ceaselessly infiltrated by agents seeking to ascribe new or different meanings to performances and place (Cloke \& Perkins, 2002). Locals 
can become vulnerable to the gaze of others (Cheong \& Miller, 2000) as competing visions of place identity impose limitations and regulations on the mobility and practice of locals (Sherlock, 2001). However, while such multi-agent interaction inscribes actions on bodies of locals (Edensor, 2001), to contend that only locals exist as pawns within photographic encounters not only constrains them disempowered, passive actors, but assumes tourists are all powerful, controlling spectators who perform independently of external forces. Rather, not only do both tourists and locals have agency within touristic encounters (Bruner, 2005), but all parties within the tourist experience are implicated by the agency of others as they perform roles in the production and consumption of touristic pleasure. Thus, a mutuality of expectations arises as agency is circumscribed structurally by the realities of economic and social inequalities, and cognitively by a mutuality of expectation of and for each other driven by precondition and historical understanding.

While locals can become restricted to playing the part of the exotic Other as subjectivities and performances of self are imprisoned within western mythologies, just as powers of agency lie with tourists, they also lie with locals. Rather than reiterating the negative consequences of commodification (Greenwood, 1978) and aestheticisation (Mowforth \& Munt, 2009), the paper suggests the emergent interplays of agency of being photographed afford opportunities for locals to harness dominant tourist narratives that facilitate social, economic and cultural gain. Locals, as social agents, are not static but undergo constant changes (Santos \& Yan, 2008). They play themselves in a fusion of self-knowledges and new knowledges of tourist actions and behaviours: inscribing and directing performances to reap the benefits of the tourist imagination (see Cohen, 1993). Thus, locals become active, knowing agents and co-performers. They are not merely mindless dupes or automatons that are gazed upon, but rather disrupt such dichotomies as they too gaze upon tourists; mobilising a two-way exchange via the "mutual gaze" (Maoz, 2006; Evans-Pritchard, 1989).

Confronting such boundaries, locals play the game of tourism as culture and tradition become alternative possibilities (Aramberri, 2001; Medina, 2003). Rather than defying stereotypes and presenting an alternative self for tourists to photograph, by acknowledging the lack of alternative possibilities, locals embrace the opportunities of the exotic Other. They actively resist or encourage mythologies and dominant narratives 
(Caton \& Santos, 2008) as they transform themselves into attractions (Bruner, 1991) to engage in profitable interaction (Bruner \& Kirshenblatt, 2005). Such enactments suggest locals retain an element of control within interplays of agency as practice does not construct a commoditised culture distinct from an 'authentic' ideal, but mobilises "ongoing, open-ended...negotiations regarding identities and their authenticity" (Medina, 2003: 367). Tourist photography therefore exists in a dynamic field imbued with poetic and political practices (Coleman \& Crang, 2002) and by celebrating the reflexivity and consciousness of local communities, "both locals and tourists engage in a coproduction: they take account of the other in an ever-shifting, contested, evolving borderzone of engagement” (Bruner, 2005: 18). Meanings of place are performed through interaction, contestation and negotiations between agents (Chronis, 2005). Thus, photographic encounters materialise as lived experiences as locals become reflexive, strategic agents moving between different stages to mobilise contextualised performances of self (Larsen, 2005).

Opportunities for empowerment further arise through the possibility of intercultural and social exchange. For some, photography creates distance as tourists gaze upon subordinated locals as photography facilitates indulgence in the flanêrie of the exoticised Other (Cohen et al, 1992; Hollinshead, 1999; Palmer \& Lester, 2007). Yet, tourism "is also about storytelling, chatting, swapping anecdotes, competitive tales" (Coleman \& Crang, 2002: 8) and tourist sites are 'foci' around which narratives and encounters are constructed through creative playfulness of embodied performance (Bruner, 2005; Cohen, 1988; Larsen, 2005). Such playfulness is not synonymous with 'post-tourist' games in contrived experiences (Urry, 1990). Rather, the immanence and unpredictability of photographic encounters coupled with the ability of tourists to instantly show locals photographs on digital cameras (see van House et al, 2004), generates a fleeting togetherness: an immersion into experience through the investment of desire (Featherstone, 1992). Therefore, while recognising differences, encounters "may blur the boundary between who is on display and who is consuming the event" (Taylor, 2001: 23, 24). Photography mobilises interaction via mutuality and trust (Cohen et al, 1992): a proximity that transforms preexisting narratives from abstract texts into embodied, somatic experiences (Bruner, 2005; Bruner \& Kirshenblatt, 2005). Thus, locals and tourists interact not as static, exclusive entities, but as continually evolving co-performers. 
Finally, as Cole (2007) suggests, "tourism is making (locals) self-conscious and proud of their culture. Their new identity... has given the local groups new political (and potential economic) capital to manipulate" (: 956). Moving to understand local perceptions of culture and motivations for mobilising culture to create opportunities for business exchange, this paper critiques assertions that commercialisation destroys local cultures (see Andereck et al, 2005; Brunt \& Courtney, 1999). Rather, echoing calls by Lankford (1994), it contends photographic practice can preserve existing, or create new cultural identities. Culture is a fluid, dynamic construct that is always in the process of being created (Bruner, 2005). As photographic encounters open the possibility of increased self-confidence and pride, the potential therefore exists for locals to utilise photography as a mechanism of mobilising and sharing culture through commercial exchange and transaction (Burns, 1999).

Focusing upon those utilise photography as a form of commercial exchange, this paper contends interplays of agency in photographic encounters not only reinforce cultures of dependency and disempowerment as performances and practice becomes imprisoned within dominant western mythologies of the exotic Other, but fundamentally realises opportunities afforded by tourist photography for empowerment, independence and selfdetermination within local communities. Attention turns first towards the complexity of multi-agent enactments of power and the mediating influence of such performances. Secondly, the paper explores opportunities for empowerment through self-directed performances within photographic encounters. Thirdly, the paper addresses the potential of photographic encounters to mobilise moments of togetherness and social exchange before finally unpacking the opportunities tourist photography affords in mobilising and sharing cultural identity. However, before moving to address these in turn, the methodological framework will be discussed.

\section{Creating Conversations \& Sharing Self: Methodological Approach}

As Bruner (2005) states, much research on the relationships between tourists and locals has been conducted through a predominantly Western lens. As this paper seeks to unpack the interplays of agency effecting locals in tourist photography, a qualitative framework was adopted. In total, 20 in-depth interviews were conducted with locals during a two-month field study. Respondents were those who are photographed by tourists on a regular basis at six key tourist sites around Cusco, Peru (see Figure 1). 
Interviews focused on: the opportunities for locals in tourism; employment before being photographed; opportunities and consequences of being photographed; and the relationship with Municipalities and Government. Participant observation was adopted as a means of accessing deeper, embodied nuances of experience and detailed field diaries were kept to record observations and reflections. An additional 12 in-depth interviews were conducted with personnel from national and local Government, the local Cusco municipality and police. Interview schedules identified key issues and ensured commonality amongst respondents. Conversations were digitally recorded and transcribed verbatim and data were analysed manually by creating thematic matrices that identified key issues. Emergent thematic structure and codes ensured analysis captured the social distribution of the issues raised and reflects the subjectivities of the experiences shared by respondents (see Flick, 2009).

(Insert Figures $1 \& 2$ here)

When interviewing locals, complexities of subjective difference extend beyond simple dichotomies of 'insider' and 'outsider' (Herod, 1999). The subjective disparity between researcher (as white, European, relatively wealthy and highly educated) and respondents (of Quechuan culture, living in poverty and poorly educated) necessitated time was spent developing relationships through trust, openness and honesty. Both respondents and researcher spent prolonged periods of time together at key tourist sites on a daily or bidaily basis. The researcher shared insights into both their personal and professional life; showing photographs of family and friends, talking openly of differences between cultures and lifestyles (e.g. income levels and relative costs of living, education, etc.), and the purpose of research, amongst many other topics. Over time, researcher-respondent relationships often became friendships as the researcher regularly lunched with locals, and was invited to attend family gatherings, seller association celebrations, day trips, dinners at respondents' homes and even friends' 'nights out' at the local Quechuan disco. It is also noteworthy that some friendships have continued beyond the research period. Consequently, interviews, when conducted at the end of the two-month period, emerged through friendship and conversation rather than interrogation (see Cloke, Crang, Goodwin, Painter \& Philo, 2003). This affirmation is highlighted as:

"(Rodriguez - translator) commented that he was very impressed as the ladies all referred to me as their friend, which he said was a strong compliment. He... said that they were all very honest 
and were telling me things that he would not have thought they would have shared" (Diary extract, Monday, $21^{\text {st }}$ June 2008).

However, where respondents worked by walking around the streets of the city (see Figure 2), building relationships became challenging. Their incessantly transient movements made even relationships of acquaintance difficult to achieve. Therefore, such respondents were secured by the researcher returning regularly to two key areas before respondents were interviewed.

While the researcher is semi-fluent in Spanish and the majority of respondents also spoke Spanish, a translator was employed for interviews in Quechuan. For interviews in Spanish, he was present only to interpret potential misunderstandings through cultural nuances of language. As Kalmer \& Threadgold (2003) suggest, "translations are never... simple encodings and decodings from one language to another" (: 146). This can result in a reliance on translator's intellectual and professional skills (Esposito, 2001), requiring a high level of trust and confidence in interpretation. While doubt inevitably pervaded the researcher-translator relationship, after every interview, both discussed the experience and raised any concerns regarding the dynamics of the interview. Such discussions resolved potential discrepancies in expectations or misunderstandings, and often enriched research findings. Conversations alleviated researcher frustrations and provided clarification of cultural context of respondents' reactions, thus allowing a greater appreciation of experiences respondents shared.

Finally, confidentiality and anonymity were upheld throughout the research. Respondents were provided research information sheets and all completed consent forms before participation. Photography consent forms were also signed by respondents who were photographed by tourists. All information was shared not only in English, but also Spanish and Quechuan as required. All respondents have pseudonyms and where sensitive issues are addressed, photographs do not identify individuals.

Agency \& Power of Photographic Encounters

First, the paper attends to the key agents of photographic encounters. As Edensor (2004) suggests, spaces and the performances enacted upon them are increasingly regulated, 
ordered and purified. Cheong \& Miller (2000), Edensor (2000) and Santos \& Yan (2008) suggest tripartite relationships exist between tourists, locals and brokers. Thus, tourist sites are composed of shifting scenes, random events and juxtapositions as agents hold competing visions of place as constructed for tourists. Thus, performances are inevitably directed by powerful agents that inscribe and condemn the bodies of locals (Edensor, 2001) according to dominant western mythologies. However, findings suggest photographic encounters are mediated not only by brokers and tour guides, but a complex web of agents extending to: tourists, local municipalities and Government, and other community members.

Locals, Government, Police \& Municipalities. First, performances are regulated by Government policy that restricts locals being photographed to designated areas within enclavic tourist sites (Edensor, 1998). As Maria, a local Government official, explained: "(the INC) have said "sell, what you want, but from here to bere"...you're not going to enter...because... it is bad for the tourist's perspective". Thus, regulation simultaneously seeks to preserve the tourist experience while ensuring locals retain the opportunity to be photographed by tourists. However, the imposition of regulation facilitates despondency as locals are removed from the decision-making process and forced to comply, thus silencing their voices and opinions. As Marlena commented: "we only obey...they... don't give the opportunity to us to say nothing, only they order"... "we came quietly, in silence and...didn't say anything to them....we were afraid".

Such action perpetuates the subjugation of locals as regulation restricts their movement. However, to limit understanding to the linear transference of power fails to comprehend parallel opportunities for empowerment. Indeed, despondence of regulatory impositions is coupled with a peace of mind and safer working environment for locals. For Lara, regulation provided security as "we are not hiding from the police... it is much better...we do not need to move to another place and so we win...Now, we can have our photos taken”. Such security through interplays of agency is further evident as locals enter collaborative working partnerships with the INC. Locals are therefore able to work without fear of retribution, while in return, they, for example, assist the INC by maintaining the cleanliness of a site. As Marlena explained: "(we) are doing....an exchange because the...INC said to (us) if you want to stay here, clean this place"... "after that they cannot take us because we are working together". Thus, 
negotiations of agencies emerge as the actions of each facilitate a sense of commitment and stability through mutual exchange and benefit.

However, where locals are photographed on the city streets, safety and security once again threatens the agency of locals. Photographing is prohibited on the city streets and activity is policed by the municipal authorities. The perceived potential for locals to create discomfort and unease for tourists by harassing them into taking photographs underpins regulation. As Luiggi commented: "sometimes they (locals)...are told "dismissed"...the tourist should enjoy taking pictures. If they need to take pictures they should ask". The stability of enclavic tourist sites gives way to an inherent transience as locals struggle to engage with tourists while simultaneously avoiding municipality officers. Consequently, the rhythms and flows of such performances exist as an endless game of "cat and mouse" (Francesco) as municipality officers escort locals being photographed from the streets, only for them to reappear immediately around another corner (Luiggi).

The presence of locals within prohibited spaces stresses the pressure to realise the financial gains of being photographed. While control primarily manifests as threat through police presence, it is not uncommon for police and municipality officers to confiscate the belongings locals use as photographic props. As Francesco commented: "the municipality has... been created for public safety which also has some units, trucks and personnel are going around to provide security for tourists". For locals, such policing measures perpetuate an environment of fear at the immanence of possible reprimand as "there are times when they take our hats, the lambs" (Yani). Vulnerability and risk permeate photography and is not limited to the physical demands of this mobile lifestyle (i.e. constantly walking, watching and carrying wares), but extends to embodied, emotional stresses as:

"... a cry came from the ally. A municipality (officer) emerged, walking abruptly across the square. He was followed quickly by (Uchi) who was crying and begging for them to return her hat" (Field diary, Saturday, 23 $3^{\text {rd }}$ August, 2008)

Consequently, the complex interplays of agency intensifies as locals performances are constrained not by western mythology, but a myriad of regulatory frameworks that simultaneously facilitate yet restrict their movements.

Locals and Tour Guides. As agents of photographic encounter, tour guides assume positions of authority as they become guardians of the tourist gaze (Urry, 1990). While 
Cheong \& Miller (2000) suggest tour guides have the least power in the tripartite relationship between brokers, within photographic encounters they are central controlling figures. Direction extends from identifying desirable landscapes to be photographed (Urry, 1990), to mediating tourists' experiences of locals (Burns, 2005). Interplays of agency are compounded as guides perform to the intense rhythms of strict time schedules. They rapidly direct tourists around sites with little time remaining for photographing locals: “(tourists) don't speak much to us...they take a photo and go...its too fast"... "the guides take all the time" (Julia). The rapidity of encounters denies interaction as tourists photograph, (occasionally) pay and leave, perpetuating distance between self and other (Palmer \& Lester, 2007). While such practice perpetuates locals as objects to be consumed visually (Caton \& Santos, 2008; Frankland, 2009; Whittaker, 2009), other guides facilitate interaction as they teach locals phrases in English (Beatriz) or inform tourist as they:

"explain about the alpaca, the llama, and sometimes...they say "they come here everyday, they come from far away to earn some money'. So, the tourists ask the guides 'bow much should I give?', 'you can give each one... or two soles or three soles"' (Lara).

Nevertheless, such mutuality remains ad-hoc as tour guides generally actively discourage tourists from photographing: "they don't explain anything and when (tourists) want to take photographs they say 'bere no, it is better that you take them...at X...they are free" (Monica). Manipulation further manifests through verbal exchange as some guides use the guise of indigenous language to undermine locals:

"sometimes they insult us in Quechuan....not all the guides do this...the other day a tourist came over and he said 'them, no, they are spoiled'. So, we could not contest it at all. We smiled, nothing more" (Lara).

The surreptitious nature of such exchanges creates tension as tour guides use their relative power to intimidate or belittle those being photographed. Consequently, feelings of resignation permeate performances by locals as they feel powerless to confront or contest guides comments: "we do not have the same education level...we remain silent and ignore them... and hope that (tourists) will see their mistake" (Julia). Thus, photography emerges through uncontested agency as guides become gatekeepers between tourists and locals. Consequently, tourists' decision-making is invariably imbued with guides' preferred behaviours, opinion and prejudice. 
Locals and Tourists. The complexities of multi-agent performances further arise in emergent relationships between locals and tourists. Tourists are mediated as aforementioned agents construct and direct their gaze (Cheong \& Miller, 2001). However, tourists also become controlling parties; striving to (re)produce the photographed other according to predetermined Western interpretations of the exotic Other (Palmer \& Lester, 2007). Thus, locals become cultural markers; commodified, living exhibits to be photographically consumed in a theatre of performance (EvansPritchard, 1989); visually ordered, tamed, controlled and consumed (Caton \& Santos, 2008; Larsen, 2009; Whittaker, 2009). Consequently, locals may become momentarily deprived of agency; unable to exist as autonomous subjects (Jean Paul Satre, cit. Garlick, 2002).

By paying for a photograph, some tourists believe they buy the right to photograph and actively stage locals until the desired shot is achieved. As Paulo recalled, "II was happy when the person took (my photo)... but when he took (my hat)....there's some absence of respect"... "I didn't say anything because he's going to (buy) some souvenir from us". Locals become puppets; resources in the consumption and (re)production of place, as tourists enframe other (Garlick, 2002). Thus, photographing reduces "buman social interaction into a commodity, erasing or replacing their (locals') pasts and histories or silencing their voices" (Cannon-Hunter, 2008: 361). The camera mobilises encounter through intrusion as tourists control and consume: "(he) holds up his large digital SLR...again, (Tula) raises her arm....Marlena) \& (Tula) request a (tip) but he ignores them... be...stretches out his arm so the camera is physically nearing ber face... another man does the same and as he ignores their requests the ladies 'tut' loudly and make their disgust known... (Marlena) commented that... it was rude and...not fair that the tourists took her photo....she started covering her face with her shawl" (Field-diary, Wednesday, $13^{\text {th }}$ August, 2008)

Performing through resistance, locals become captured; objectified others in tourists' procurement of place and the enlightenment of self-as-tourist (Garlick, 2002).

Such despondency is further perpetuated as tourists control financial exchanges:

"the tourists take photos from up (from the top of the site down onto the locals)... they (leave)... what can we do? We are in Gods hands"... "there are some... who take photos from above and they... give some money to (us). Its nice... I say to them, 'God bless you'”... "there's a lot of resignation"... "if its impossible, what can we do?... we are quiet and smiling" (Alba) 
The voluntary nature of payment combined with tourists' willingness to pay and advice from guides generates highly unpredictable quantity and frequency of income. Locals' reliance on every financial exchange highlights the ever-present threat of immanent market failure that is evident as even when tourists give: "one cent... you cannot throw that away, you have to say thank you" (Marlena). However, unpredictability is compounded as tourists give "money that we cannot use" (Ursula). Yet, the humility and gratitude locals express at receiving tips reflects their desire to maintain personal integrity and a wider cultural desire to respect tourists and provide a positive experience: 'T say thank you, that's all we say... all the time we think about the tourists, maybe...she's thinking we're asking too much money for that...I don't want the tourists to think that... maybe I am a robber" (Alba)..

Locals and the Non-Photographed Other. The final agents at play are other community members who are not photographed for money, but sell handicrafts alongside those who are at tourist sites. As Dogan (1989) realises, tourism affects community habits, routines, social lives, beliefs and values that can mobilise degrees of internal social conflicts. Communities are not homogenous blocks, but exist as a fragmented and continually changing network of social ties (Sherlock, 2001). It is between these two groups that potential tensions arise as sellers echo concerns from Government to protect tourists' experiences and limit pressures to take photographs. As Glenda commented: "they (locals) are coming to have their photos taken and... some, not many...they demand and sometimes (tourists) do not give, they give more or less fifty centimos...but they want more"... "sometimes they annoy the tourists". Likewise, Julie felt pressure placed on tourists to photograph creates a "bad impression".

Potential tensions arise as each party holds conflicting opinion of photography as either harassing tourists and realising 'easy money' for locals, or as a source of legitimate employment. Such interplays invariably mobilise potential for unrest within intercommunity relations. Frustrations are manifest as local handicraft sellers question the work ethic of those being photographed. As Fina commented: "they like the easy life, no?...They are not doing anything to earn their money". While some sellers, like Julia, felt being photographed required courage and confidence, for many it is an 'easy' option as: "they don't know, or earn through sweat... as others do" (Lucianna). While Kathy acknowledges lack of education as perpetuating dependency, friction imbues community relations and physically manifests as those being photographed and those selling form separate groups 
at sites; sitting and lunching separately with very little communication. Such discontent potentially undermines residents' sense of shared identity as disagreement imbues agreement on suitable pathways of development (Sherlock, 2001) and the appropriateness of photography as a form of employment.

Spaces of exclusion also exist as locals selling handicrafts form intercommunity associations. Unable to realise the official papers required for membership, those being photographed are prohibited from joining. Politics perpetuate such division as: "I can't sell with the other people because I am not in the roll and I need to be but they don't want me" (Alba). Membership of sellers associations are governed not only by place of residence, but by financial contribution. For many like Inti, this is problematic as: "there are many people like (me) working, but they are not in a group... (we) have to pay...that's a problem". Unable to pay the joining fee, those being photographed become caught in a cycle of isolation and exclusion; their social and economic mobility determined by the practices and politics of a complex web of agents each striving to meet their own individual needs.

Nevertheless, working within the boundaries of agency interplays, locals being photographed collaborate and devise working rotas to minimise competition. As Lara commented: "twelve of us rotate...we rotate because sometimes others come here from the community". Likewise, those who work together share their income: "they always give us a sol. So, we share it thirty centimos or fifty. If there are two of us, fifty, if there are three of us, thirty" (Yani). The resultant social cohesion generated by group collaboration partially negates the unpredictable nature of income as respondents ensure an even distribution of daily earnings. Such practice facilitates the development of social control and empowerment (Cole, 2007) and it is to this that attention now turns.

\section{Self-Directed Performances \& Spaces of Empowerment in Photographic Encounters}

Tourist-local relationships are never permanent or equal. However, to condemn the fleeting, transitory nature of such interaction as superficial performances spawning breeding grounds of exploitation, dishonesty and stereotype formation, fails to comprehend the opportunities photography affords as an entrepreneurial activity. Moving beyond Greenwood's (1978) structuralist understanding of commodification as perverse violation that "in effects robs people of the very meanings by which they organise their life" (: 
137), this paper suggests being photographed can mobilise opportunity through ingenuity. The very nature of some tourist attractions as 'overtly staged' opens opportunities for locals to engage in "a more subtle, covert and insidious form of staging" (Cohen, 1988: 57) as they begin to see themselves in terms of how they are represented by the tourism industry (Cohen et al, 1992; Teymur, 1993) and use this to realise gains without compromising social, cultural and environmental integrity (Chalfern, 1987). In confronting the limited potential of employment opportunities available to them, locals draw upon initiative and personal skills to become agents of self-directed performances; living and active performers, who create and reproduce self within tourist discursive demands of the exotic Other (see Edensor, 2001; Evans-Pritchard, 1989; Palmer \& Lester, 2007).

Indeed, while tourism can benefit only a small proportion of locals and foster social polarisation and market failure via uneven distribution of economic benefits (Tosun, 2002), photography can provide 'informal' members of society an alternative means of employment. Many like Yani, reflected upon their transition from agriculture to photography: "I had to leave the fields....there wasn't sufficient money"... "now there is more". Where some previously found employment as market sellers, washing clothes or cleaning houses, for others the transition to being photographed was borne out of family breakdown or to escape abusive relationships. For Alba, breakdown transpired as family members migrated or passed away leaving her alone in a role-gendered society: "my life is very sad because I have one brother but... he lives in another...place far away from bere. He couldn't come when my father and my mother died. I'm alone. I worked the farm but it's so difficult because I'm a woman you know, in the country, the man's labour... That's the reason I'm here working".

Photography provides a means of alleviating hardship; offering a pathway to improving respondents' quality of life and standards of living (McCool \& Martin, 1994). It is combined with simultaneous performances as locals utilise several skills to maximise their earning potential: "when I am having my photograph taken...I take care about (my) alpaca... and doing... the weaving" (Alba). As Mila reflected, the resultant increase in income can enable families to purchase food and clothing as "in the times of rain, there was no food. We were starving with hunger.... all of the children were malnourished". Now, despite the unstable nature of income from tourists, respondents like Beatriz commented: "I am happy working bere because I can get sometimes change or twenty or maybe less. Sometimes I am saving to buy rice...for my children or for myself....or I can put the money to buy clothes”. For others, being photographed 
provided access to health care that was previously unattainable as "the money that I get is good for me because I can go to the hospital to get some treatment" (Marlena). Improvements in social accessibility extend to infrastructure and housing as some like Lara, are now able to build their own houses.

While it would be naive to purport tourist photography erodes the foundations of tourist photographic performances as seeking out the exotic Other, for some, being photographed mobilised sufficient wealth that their children can be educated and therefore realise alternative future employment. The integrity and commitment of respondents to realising such improvement is exemplified by Beatriz as: "Its not too much but (it) is still good for my family...so I can educate them. I am not a drunk woman...I save money"... "all my children know how I can get money here...now...one is a driver, one a storeman. Well educated, with secondary complete...they are good people working". Whilst touristic mythologies constrain the subjectivities of current working generations, the economic benefits mobilise the future potential of the next generation through funding education and skill development. Being photographed was not an aspiration respondents held for either themselves or their children: "all the things that (we) do are...for the education of our children"... "they're working in handicrafts not to come and sit...only us, we're only us here. Someday we're going to die, maybe nobody is going to come" (Marlena). Being photographed is therefore a finite practice. It provides a means to an end; a springboard to dreams and alternative futures as respondents shared their hopes and aspirations: "we will have a business" (Mila)... "we will have a stall and sell lots of things" (Yani).

\section{Fleeting Moments of Togetherness \& Social Exchange:}

Thirdly, being photographed provides the opportunities for intersubjective communication and exchange. Tourism is a process that brings together people via social interaction (Chalfern, 1987; Sharpley, 1994) and touristic encounters emerge as performances of embodied interplay between agents. While such interaction can mobilise temporary, shallow relationships founded in artificial expectations of the exotic Other (Burns, 2005), to limit understandings of interaction as meaningless not only perpetuates the objectification of locals, but denies their active role as knowledgeable, empowered agents within photographic encounters. Rather, fleeting togetherness affords opportunities for creative and playful exchanges (Bædernholt et al, 2004; Cohen, 1988; 
Edensor, 1998) that shape and influence tourists' experience of place and locals. Indeed, digital photography renegotiates the position of tourists as agents of power and locals' lack of agency as photographed subjects. Photography mobilises two-way encounters as tourists can show (and locals can ask to see) photographs using the instant view function and (at times) delete those to which subjects object (van House et al, 2004).

Thus, photography produces as it consumes (Haldrup \& Larsen, 2003); creating "unusual moments of intimate co-presence rare outside the limelight of the camera eye" (Larsen, 2009: 253). It creates a state of constant dynamic play as the material and intangible spaces of self and other exist within the ever-changing landscape of touristic demands. While photography continues to instil fear in some communities (see Hoskins, 2009), in Cusco locals have grown accustomed to its presence. They harness its potential as a source of economic, social and cultural gain; actively posing with and positioning tourists in 'group' poses, and provide reassurance and support as they hand tourists lambs to hold (see Figure 3). Thus, locals perform (re)incarnations of the exotic Other; actively transforming their selves and tourists by directing social exchanges through action, gesture, verbal direction. Indeed, despite constraints of time and language, social interaction enlivens the photographic encounter and becomes part of the experience (Edensor, 2000). Together, locals and tourists produce social relations (Larsen, 2009) as both initiate conversation and mobilise socio-cultural exchange. As Paulo comments: "I ask (tourists) what kind of job they do...where are they from...I always speak with them about what they do....to gain some experiences to tell my people", while Marlena tells tourists "about our children". Likewise, Yani said that "sometimes (tourists) ask us how much it costs... about the lamb, is it a girl or boy, if it drinks milk or not".

(Insert Figure 3 here)

Communication also materialises through embodied togetherness as playfulness fuses predictable habit with unpredictable, immanent action. Interaction becomes "spontaneous...it's all natural with us, they bug us...its simply a hug, nothing more" (Julia). Immanence of togetherness therefore underpins photography as taking the photograph becomes only one part of a deeper exchange:

"There is a lot of langhter as the five chat together...the two men pose, their arms around (Alba) and (Clarissa)....the photographer calls the ladies by their names" (Field diary, Tuesday, $12^{\text {th }}$ August 2008) 
While Edwards (1996) suggests immediacy is often confused with intimacy as tourists capture markers of encounter rather than relationships, such conceptualisation fails to acknowledge the context of touristic encounter. By their very nature, photographic encounters are fleeting and can never hold intimacy as experienced in prolonged personal relationships. The intimacy of photographic encounter is not synonymous with closeness through affection, but as momentary pleasure manifest through trust, respect and togetherness. As Paulo commented: "we talk with them like a brother or something. They ask maybe my name and I give my name...we talk like that. Trusting”. Such encounters mobilise a mutually beneficial relationship that both effectively combines commercial exchange with the playfulness embedded in human nature, that for some is prolonged and sporadically reignited through embodied visual reflexivity (Scarles, 2009).

Through fleeting exchanges, locals transcend their position as symbolic markers. They become people performing the exotic Other rather than interchangeable faceless markers on postcards, brochures or websites. Such encounters can negate negative stereotypes that locals merely, to use MacCannell's (1979) concept of staged authenticity, pose in brightly coloured clothing before resuming 'real' life at home. Opportunities arise to enliven myths as tourists can acquire general insights into the significance of local dress, traditions and lifestyles. Social exchange also mobilises increased confidence and assurance amongst locals (Sharpley, 1994), and over time provides opportunities for some, like Beatriz, to acquire basic knowledge of languages and can ignite the desire to learn. Nevertheless, many respondents also commented on language hindering communication as: "we don't talk...we do not understand them and they don't understand us unless they speak Spanish" (Lara). Thus, photographic encounters exist as a series of improvisations (Edensor, 2001) as tourists and locals find pathways to facilitate togetherness.

\section{Mobilising and Sharing Cultural Identity}

Finally, attention turns to performances of cultural identity. Traditional structuralist approaches suggest tourism can adapt cultural values and practices (Ap \& Crompton, 1993), destroy culture (Brunt \& Courtney, 1999), mobilise cultural commercialisation (Andereck et al, 2005) and initiate long-term changes in culture and cultural identity (Pearce et al, 1998). However, findings support those of Lankford (1994) as the 
interplays of agency within tourist photography simultaneously revitalise existing elements of culture and mobilise new incarnations of culture and identity (see also Andereck et al, 2005; Bruner, 2005; Haralambopoulos \& Pizam, 1996; Santos \& Yan, 2008). While Sherlock (2001) likens commodification to the creation of a pastiche of experiences, photographic encounters mobilise increased cultural awareness, pride and confidence amongst locals. As Juan commented: "people laughed a lot at us, they... ashamed us"... "Now) we are not ashamed about our clothes... We are learning to respect our (culture)... we are proud now to...produce our clothes and we take care about these clothes...we are showing our culture" (see Figure 4).

(Insert Figure 4 here)

Such revitalisation and transformation of cultural identity positions locals as central in the 'sharing process' (Burns, 1999). In providing opportunity for social exchange, photography mobilises intercultural exchange as both locals and tourists share snippets of their lives. Thus, as Besculides, Lee \& MacCormick (2002) suggest, locals learn about, share and mobilise enactments of their own culture and that of tourists as they communicate through intercultural transactions. As Paulo reflected: "we dress different, in different ways...I would like to show to them to look (at) us doing our custom"... "they can take the value of our work, looking how we... are working. It's good for us". He continues: "some people comes and want to sit like me...I help then, I teach....them how they can do it. This is good". Locals explain techniques of weaving, traditions, differences between regions, and at times attempt to teach tourists particular skills, thus initiating a playfulness to photographic encounters. As Inti recalls teaching some tourists to weave: "they ask how I work...teach us how to do"... "I taught them, but they don't learn (laughs)".

The production of culture as a commodity therefore emerges as a complex negotiation of belonging and social capital (Chaney, 1993, cit. Sherlock, 2001). As Mila commented: "we always use them (traditional clothes), no? now....the ones we use for the farm have more black in them, nothing more... The only thing to change is we have more tassels"... "it is nicer...for the tourists". Locals too consume their identity as they perform their self as lived (Sherlock, 2001). The dynamic nature of culture is reflected as locals adapt clothing or incorporate alternative designs into weavings. For some, like Mila, such performances mobilise subtle enhancements as they share their culture not only as lived, but as perceived desirable for 
tourists. That said, while locals actively preserve aspects of culture they deem photogenic, such preservation may present less desirable outcomes for other community members or indeed, other tourist destinations. Such negative effects of commodification are further explored by authors such as Brunt \& Courtney (1999) while, Besculides, Lee \& McCormick (2002) propose residents have little concern for the negative impacts that tourism may yield.

This paper proposes that it is not through lack of concern, but rather a lack of awareness of the potential effects of tourism as locals focus primarily on potential gains. In striving to realise employment and subsequent income, locals and culture are constantly at and in play as "tourism is transforming the materiality of many 'real' places" (Sheller \& Urry, 2004: 4). Destinations are mobilised in ways that agents deem them fit for play as locals respond to that which tourists deem fit to photograph. Places and culture are endlessly shifting as they are performed and enacted through multiple, often contested meanings. Indeed, the potential risk exists whereby "people and places get caught upon within the swirling vortex of these systems of tourism mobilities" (ibid. p.5). Thus, in living for and in the moment, locals may experience cultural blindness as the need to survive obscures potential longer term detrimental effects of tourist photography.

\section{CONCLUSIONS}

This paper has attended to the agency of locals in photographic encounters with tourists. In identifying the role of tourist photography as a tool for both consuming and producing the tourist experience, it unpacked the complexities of the seemingly fleeting intersubjective relationships between agents of the photographic encounter. In doing so, it contends that a series of interplays of agency emerge within which locals negotiate the complexities of performing amongst and alongside larger, third party forces. As locals remain bound within western mythologies of the exotic Other, the paper reflects upon practices that not only perpetuate cycles of dependency and disempowerment that sustain spaces of exclusion with local communities, but also the opportunities afforded by tourist photography to mobilise practices of empowerment and facilitate the development of constructive socio-cultural shifts in community frameworks. 
Photographic encounters emerge through a complex web of agency, politics and power and a multiplicity of agents come together through a series of embodied performances (see Edensor 1998, 1999, 2001). Building upon work by authors such as Cheong \& Miller (2000) and Sherlock (2001) who propose tripartite relations between tourists, locals and brokers, the paper extends such conceptualisation to practices of Government and fellow community members. Spaces of photographic encounter and the performances locals enact within these spaces become enmeshed in highly regulated and ordered practices. Thus, locals become confined and restricted within both their bodies and in the spaces where they perform. The rhythms and flows of photographic interactions are mediated through a fusion of formal and informal regulation as locals perform through obligation, resignation and despondency. Their performances become dependent upon the demands and wants of others as they struggle to position themselves and realise opportunities of being photographed in a highly transient, unpredictable and at times, volatile environment.

However, the paper proposes that photographic encounters are no longer restricted to linear, one-way practices of capturing the 'exotic' other as tourists photograph in accordance with their predetermined tourist gaze as constructed through tourism media or directed performances of tour guides. Locals do not simply become locked within dominant discourses driven by replication and repetition with an undercurrent of subordination and control. Rather, opportunities for playfulness and self-direction arise as locals become situated as living and active agents. Through ingenuity, locals become repositioned as directors; utilising the potential of their mediated stereotype to mobilise commercialised photographic encounter as an alternative means of income and employment. Thus, in providing a relative increase in income, being photographed facilitates poverty alleviation; increasing access to food, education, health care and clothing. Such empowerment is further compounded through improved social cohesion and collaboration.

Yet, empowerment does not arise solely from economic gain, but moments of intersubjective togetherness and social exchange. Whilst often dismissed, such fleeting encounters are enlivened as spaces of creativity and playfulness as locals themselves become positioned as directors and mediators of the tourist encounter. Alternatively, photography opens new possibilities for sharing and mobilising cultural identity; 
stimulating pride and intercultural exchange. Locals and tourists engage in renegotiations of self and other as differences are momentarily blurred and togetherness arises through mutual trust, comfort and playfulness. Thus, the effects of tourist photography should not be imprisoned within disempowering practices that reinforce negative cycles of dependency, commodification and social repression. Rather, existing within a complex web of agency and power, photography simultaneously represses and ignites opportunity as locals become immersed in a series of intersubjective negotiations between agents of the photographic encounter. 


\section{REFERENCES}

Adler, J. (1989). Origins of Sightseeing. Annals of Tourism Research 16: 7-29.

Albers, P.C. \& James, W.R. (1984). Utah's Indians and popular photography in the American West: a view from the picture postcard. Utah Historical Quarterly 52(1): 72-91.

Andereck, K.L., Valentine, K.M., Knopf, R.C. \& Vogt, C.A. (2005). Residents' Perceptions of Community Tourism Impacts, in Annals of Tourism Research 32(4): 10561076.

Ap \& Crompton, (1993). Residents' Strategies for Responding to Tourism Impacts, Journal of Travel Research, 32(1): 47-50.

Aramberri, J. (2001). The Host Should Get Lost: Paradigms in the Tourism Theory, in Annals of Tourism Research 28(3): 738-761.

Baederholt, J., Haldrup, M., Larsen, J. \& Urry, J. (2004). Performing Tourist Places, Aldershot: Ashgate.

Besculides, A., Lee, M.E. \& McCormick. P.J. (2002). Residents' Perceptions of the Cultural Benefits of Tourism, in Annals of Tourism Research 29(2): 303-319.

Bruner, E.M. (1991) Transformation of Self in Tourism, in Annals of Tourism Research, 18: 238-250.

Bruner, E.M (2005) Culture on Tour: Ethnographies of Travel, Chicago: Chicago press.

Bruner, E.M. \& Kirshenblatt-Gimblett, B. (2005). Massai on the Lawn: Tourist Realism in East Africa, in Bruner, E.M (ed). Culture on Tour: Ethnographies of Travel, Chicago: Chicago Press: 33-70.

Brunt, P. \& Courtney, P. (1999). Host Perceptions of Sociocultural Impacts, in Annals of Tourism Research 26(3): 493-515. 
Burns, P. (1999) Culture, Tourism and the local-global Nexus, in Wahab, S \& Cooper, C. (eds). Tourism in the Age of Globalisation, ? : 290-306.

Burns, P. (2005). An Introduction to Tourism and Anthropology, London: Routledge.

Cannon-Hunter, W. (2008). A typology of photographic representations for tourism: depictions of groomed spaces. In Tourism Management, 29: 354-365.

Caton, K. \& Santos, C.A. (2008). Closing the Hermeneutic Circle? Photographic Encounters with the Other. In Annals of Tourism Research 35(1): 7-26.

Chalfern, R.M. (1979). "Photography's Role in Tourism: Some Unexplored Relationships." Annals of Tourism Research 6(4): 439-447.

Cheong, S.M. \& Miller, M. (2000). Power and Tourism: A Foucauldian Perspective, in Annals of Tourism Research 27(2): 371-390.

Chronis, A. (2005). Coconstructing Heritage At The Gettysburg Storyscape, in Annals of Tourism Research 32(2): 386-406.

Cloke, P. \& Perkins, H.C. (2002). Commodification and Adventure in New Zealand Tourism, in Current issues in Tourism, 5(6): 521-549.

Cloke, P. Crang, P. Goodwin, M. Painter, J.M \& Philo, C. (2003). Practising Human Geography, Sage Publishing, London.

Cohen, E. (1988). Authenticity and Commoditization in Tourism, in Annals of Tourism Research, 15: 371-386.

Cohen, E. (1993) The Study of Touristic Images of Native People: Mitigating the Stereotype of a Stereotype, in Pearce, D.G \& Butler, R.W. (eds.). Tourism: Critiques and Challenges, London Routledge: 36-69. 
Cohen, E., Nir, Y. \& Almagor, U. (1992). Stranger-local Interaction in Photography, in Annals of Tourism Research, 19: 213-233.

Cole, S. (2007). Beyond Authenticity and Commodification, in Annals of Tourism Research, 34(4): 943-960.

Coleman, S. \& Crang, M. (2002). Grounded Tourists, Travelling Theory, in (eds). Tourism: Between Place and Performance, Oxford: Berghahn: 1-20.

Crang, M. (1997a). Picturing Practices: research through the tourist gaze. Progress in Human Geography 21(3): 359-373.

Crang, P. (1997b). Performing The Tourist Product, in Rojek, C. \& Urry, J. (eds). Touring Cultures: Transformations of Travel and Theory, Routledge Publishing, London: 137-154.

Crouch, D. \& Lubbren, N (2003). Visual Culture and Tourism, Berg Publishing, Oxford.

Dann, G.M. (1996). The People of Tourist Brochures, in Selwyn, T. (ed). The Tourist Image: Myths and Myth Making in Tourism, Chichester: Wiley.

Dogan, H.Z., 1989. Forms of Adjustment: Sociocultural Impacts of Tourism. Annals of Tourism Research 16, pp. 223-239.

Evans-Pritchard, D. (1989). How “They" See "Us": Native American Images of Tourists, in Annals of Tourism Research, 16: 89-105.

Edensor, T. (1998). Tourists at the Taj: Performance and Meaning at a Symbolic Site, Routledge Publishing, London.

Edensor, T. (2000). "Staging Tourism: Tourists as Performers." Annals of Tourism Research $7(2): 322-344$.

Edensor, T. (2001). Performing Tourism: Staging Tourism: (Re)Producing Tourist Space and Practice. Tourist Studies 1(1): 59-81. 
Edensor, T. (2004). Reconstituting the Taj Mahal: tourist flows and glocalisation, in Sheller, M. \& Urry, J. (eds). Tourism Mobilities: places to play, places in play, London: Routledge: 103-115.

Edwards, E. (1996). Postcards: Greeting from Another World, in Selwyn T. (ed). The Tourist Image: Myth and Myth-making in Tourism, Wiley Publishing, Chichester: 197-221.

Esposito, N. (2001). From Meaning to Meaning: The Influence of Translation Techniques on Non-English Focus Group Research. Qualitative Health Research 11(4): 568-579.

Featherstone, M. (1992). Cultural Theory and Cultural Change. London: Sage Publications.

Flick, U. (2009). An Introduction to Qualitative Research. London: Sage Publications.

Frankland, S. (2009). The Bulimic Consumption of Pygmies: Regurgitating an Image of Otherness. In Robinison, M. \& Picard, D. (eds). The Framed World: Tourism, Tourists and Photography, London: Ashgate: 95-116.

Franklin, A. \& Crang M. (2001). The Trouble With Tourism and Travel Theory. Tourist Studies 1(1): 5-22.

Garlick, S. (2002). Revealing the Unseen: Tourism, Art and Photography, in Cultural Studies, 16(2): 289-305.

Greenwood, D. (1978). Culture by the Pound: An Anthropological Perspective on Tourism as Cultural Commodification, in Smith, V.L. (ed). Hosts and Guests: The Anthropology of Tourism. Oxford: Blackwell: 129-138.

Haldrup, M. \& Larsen, J. (2003). The Family Gaze, in Tourist Studies 3: 23-46. 
Haralambopoulos, N. \& Pizam, A. (1996). Perceived Impacts of Tourism: The Case of Samos, in Annals of Tourism Research 23(3): 503-526.

Herod, A. (1999). Reflections on interviewing foreign elites: praxis, positonality, validity and the cult of the insider. Geoforum 30: 313-327.

Hollinshead, K. (1999). Surveillance of the worlds of tourism: Foucault and the eye-ofpower, in Tourism Management, 20(1): 7-23.

Hoskins, J. (2009). The Camera as Global Vampire: The Distorted Mirror of Photography in Remote Indonesia and Elsewhere. In Robinison, M. \& Picard, D. (eds). The Framed World: Tourism, Tourists and Photography, London: Ashgate: 151-168.

Jokinen, E. \& Veijola, S. (2003). Mountains and Landscapes: Towards Embodied Visualities, in Crouch, D. \& Lubbren, N. (eds). Visual Culture and Tourism, Berg Publishing, Oxford: 259-278.

Kamler, B. \& Threadgold, T. (2003). Translating Difference: questions of representation in cross-cultural research encounters. Journal of Intercultural Studies 24(2): 137-151.

Lankford, S.V. (1994). Attitudes and Perceptions Toward Tourism and Rural Regional Development, Journal of Travel Research 32(4): 35-43.

Larsen, J. (2005). Families Seen Sightseeing: Performativity of Tourist Photography, in Space and Culture, 8: 416-434

Larsen, J. (2009). Geographies of Tourist Photography: Choreographies and Performances. Downloaded on $15^{\text {th }}$ July 2009 from: http://www.rucsdigitaleprojektbibliotek.dk/bitstream/1800/3848/1/GEOGRAPHIES OF TOURIST PHOTOGRAPHY CHOREGRAPHIES AND PERFOR.pdf

MacCannell, D. (1979). Staged Authenticity: arrangements of social space in tourist settings. American Journal of Sociology 79(3): 589-603. 
McCool, S.F. \& Martin, S.R. (1994). Community Attachment and Attitudes Towards Tourism Development, in Journal of Travel Research 32(4): 29-34.

Markwick, M. (2001). Postcards From Malta: Image, Consumption and Context. Annals of Tourism Research 28(2): 417-438.

Martinez, M.J. \& Albers, P. (2009). Imagining and Imagining Pueblo People in New Mexico Tourism. In Robinison, M. \& Picard, D. (eds). The Framed World: Tourism, Tourists and Photography, London: Ashgate: 39-62.

Maoz, D. (2006). The Mutual Gaze, in Annals of Tourism Research, 33(1): 221-239.

Medina, L.K. (2003). Commoditizing Culture: Tourism and Maya Identity, in Annals of Tourism Research, 30(2): 353-368.

Mellinger, W. (1994). Towards a Critical Analysis of Tourism Representations. Annals of Tourism Research 21(4): 756-779.

Mowforth, I. \& Munt, M. (2009). Tourism and Sustainability: Development, Globalisation and new tourism in the Third World, London: Routledge.

Palmer, C. \& Lester, J. (2007. Stalking the cannibals: photographic behaviour on the Sepik River, in Tourist Studies 7(1): 83-106

Pearce, P, Kim, E. \& Lussa, S. (1998). Facilitating Tourist-Host Social Interaction, in Laws, E., Faulkner, H.W. \& Moscado, G. (eds). Embracing and Managing Change in Tourism, Routledge: 347-364.

Santos, C. \& Yan, G. (2008). Representational Politics in Chinatown: The Ethnic Other, Annals of Tourism Research 35(4): 879-899.

Scarles, C. (2009). Becoming tourist: renegotiating the visual in the tourist experience, in Environment and Planning D: Society and Space, 27(3): 465-488. 
Sharpley, R. (1994). Tourists, Tourism and Society, Huntingdon: Elm.

Sheller, M. \& Urry, J. Places to play, places in play. In (eds). Tourism Mobilities: Places to Play, Places in Play, London: Routledge, pp.1-10.

Sherlock, K. (2001). Revisiting the concept of hosts and guests, Tourist Studies, 1(3): 271295.

Sontag, S. (1976). On Photography, Penguin Books Ltd, London.

Taylor, J.P. (2001). Authenticity and Sincerity in Tourism, in Annals of Tourism Research, 28(1): 7-26.

Teymour, N. (1993). 'Photourism' or the epistemology of photography in tourism, in Tourism in Focus, 6: 6-16.

Tosun, C. (2002). Host Perceptions of Impacts: A Comparative Tourism Study, in Annals of Tourism Research, 29(1): 231-253.

Urry, J. (1990). The Tourist Gaze: Leisure and Travel in Contemporary Societies, $1^{\text {st }}$ ed, Sage Publishing, London.

Waitt, G. \& Head, L. (2002). Postcards and frontier mythologies: sustaining views of the Kimberley as timeless, Environment and Planning D: Society and Space 20: 319-344.

Whittaker, E. (2009). Photographing Race: The Discourse and performances of Tourist Stereotypes. In Robinison, M. \& Picard, D. (eds). The Framed World: Tourism, Tourists and Photography, London: Ashgate: 117-138. 


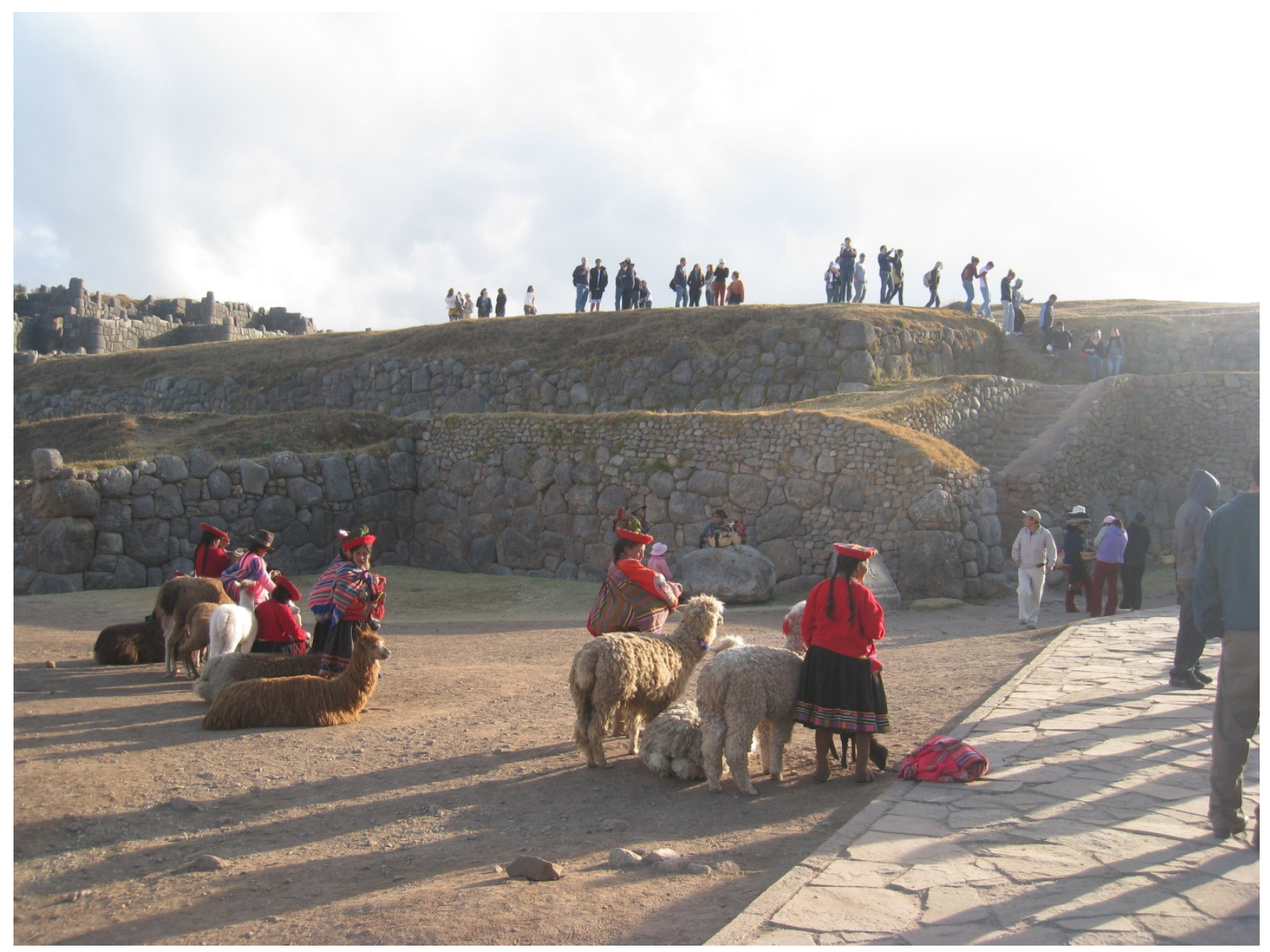

Figure 1: Key Tourist Site, Cusco, Peru, Authors Own Photograph 


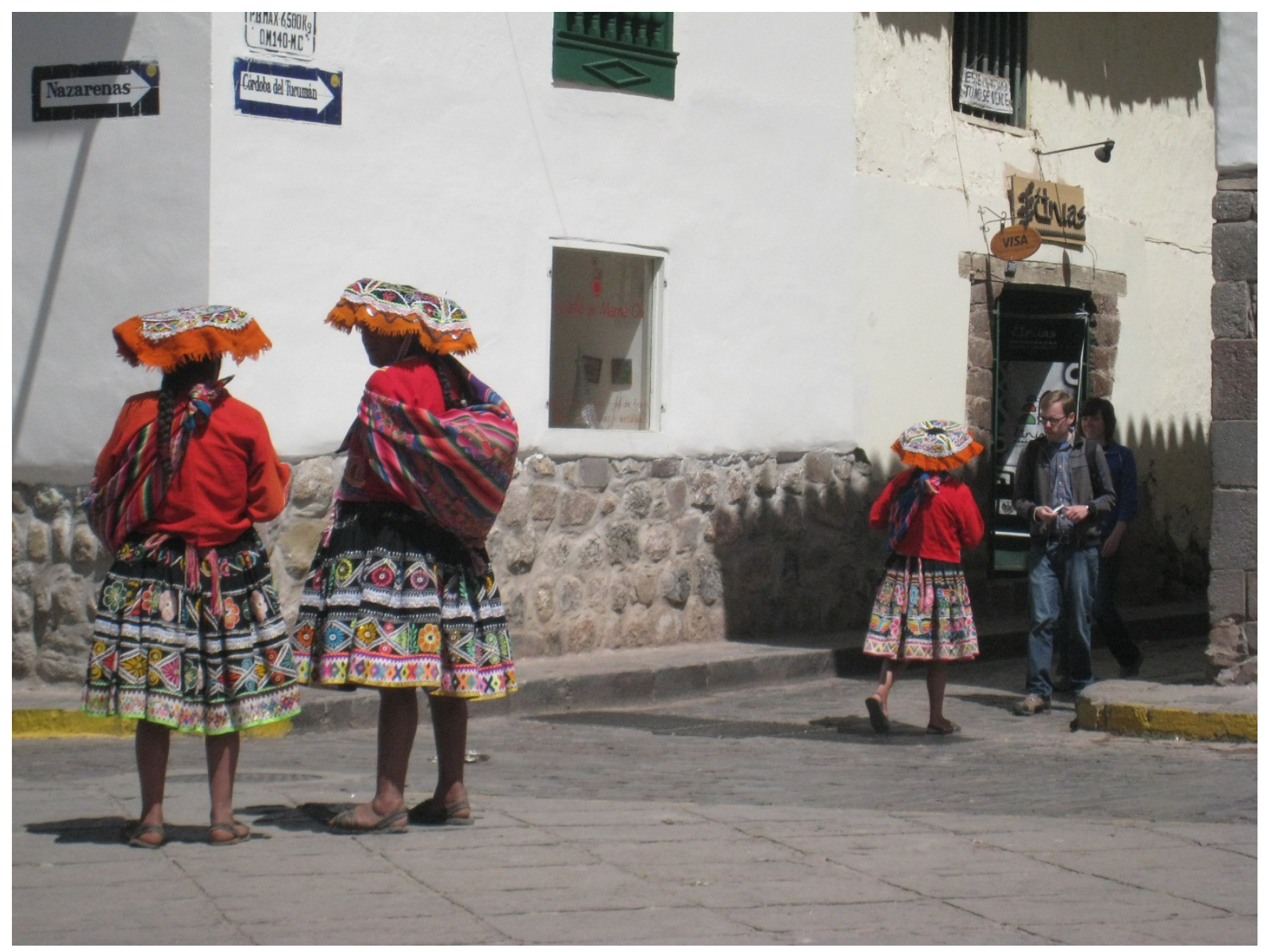

Figure 2: Being Photographed on the City Streets, Cusco, Peru, Authors Own Photograph

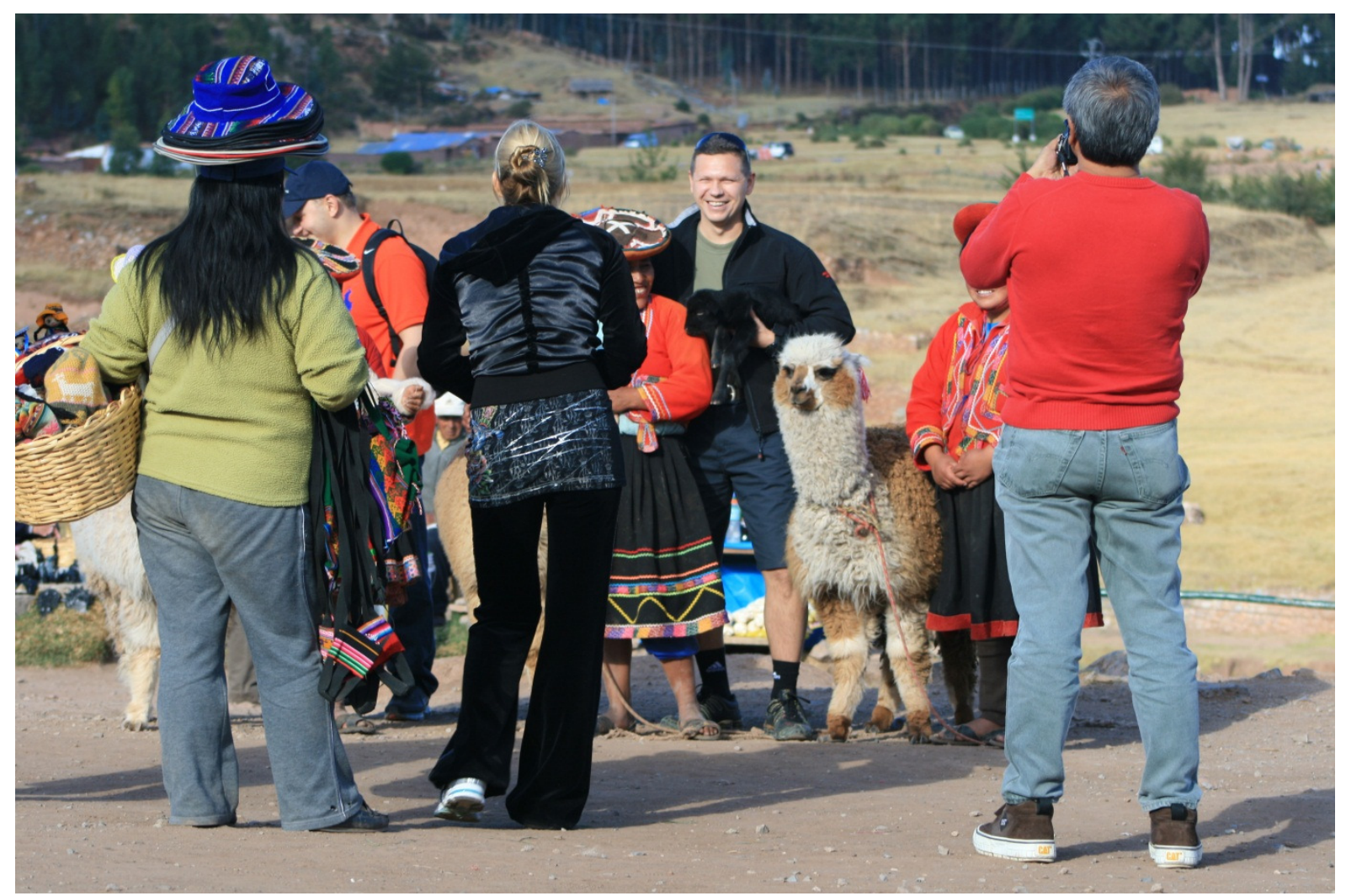

Figure 3: Fleeting Moments of Togetherness, Cusco, Peru. Authors Own Photograph 


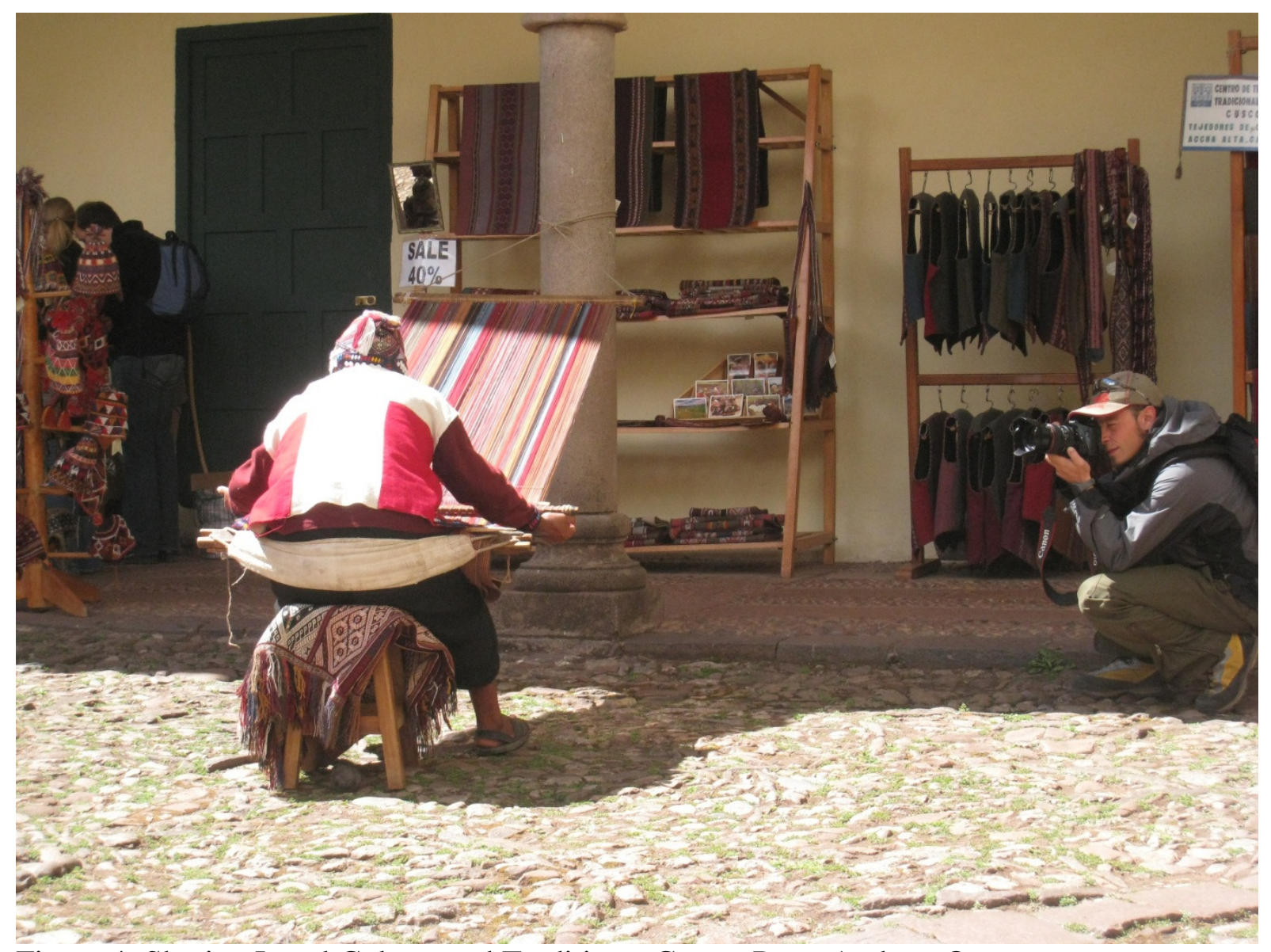

Figure 4: Sharing Local Culture and Traditions, Cusco, Peru. Authors Own Photograph 